Journal of African Real Estate Research

Volume 3, Issue 2

\title{
Household and Neighbourhood Responses to House Burglary in Ibadan
}

\author{
Ayobami Popoola ${ }^{1}$, Moruf Alabi $^{2}$, Adeshina $\mathrm{Ojo}^{3}$, and Bamiji Adeleye ${ }^{4}$ \\ ${ }^{1}$ Department of Town and Regional Planning, University of KwaZulu-Natal, South Africa \\ 2-3 Department of Urban and Regional Planning, University of Ibadan, Nigeria \\ ${ }^{4}$ Department of Urban and Regional Planning, Federal University of Technology, Nigeria
}

To cite this article: Popoola, A., Alabi, M., Ojo, A. \& Adeleye, M. (2018). Household and Neighbourhood Responses to House Burglary in Ibadan. Journal of African Real Estate Research, 3(2), pp.150-178. DOI: 10.15641/jarer.v3i2.575.

\begin{abstract}
House burglary is a prevailing issue in Nigeria owing to the inefficiency of formal security institutions in dealing with incidences of urban household burglary. This study examines households and neighbourhoods' responses to household burglary in Ibadan, Nigeria. In-depth interviews and household questionnaires were the primary data collection tools. A crosssectional survey design was adopted while a multi-stage sampling technique was used to select 299 respondents. Analysis of Variance confirmed the research hypothesis which suggested that burglary crimes committed differ significantly among residential neighbourhoods $(F=3.012)$. Burglary occurred mostly in houses that were accessed through footpaths. Furthermore, females reported witnessing burglaries more than males. Neighbourhood responses to burglary include the use of gates, private security outfits and local vigilante groups. Individual households relied on burglary proof windows and door; broken bottles and wire fencing for protection. The intensity of crime in suburban areas impacts residential relocation and property values. Neighbourhood planning and good housing design remain other means through which easy accessibility by burglars can be prevented.
\end{abstract}

Keywords: House Burglary; Household Response; Neighbourhood Response; Ibadan

\section{Introduction}

The development trends of large urban regions have destructive consequences for societal stability. Changing cities have created havens for international terrorist and criminal networks (Philip, 2002). The resultant effects of urbanisation, poverty and unemployment in developing countries are unsafe neighbourhoods and increased crime rates (Wrigley-Asante, 2016). These issues of inequality pose a significant threat to livelihood and residential property. Burglary crime, which is defined as the breaking into another person's home with the aim of stealing a particular asset at any time (Hale, 1990 cited in Anderson, 2011; Randa, 2015), is a common phenomenon in 
urban areas. It remains one aspect of social crime which is ubiquitous in every neighbourhood globally and one which needs serious attention (Grabosky, 1995). Muggah (2012) reports that property crime in the form of burglaries, along with violent crimes, are on the rise within cities, globally. Studies by Weisheit and Donnermeyer (2000), Lee (2006), National Centre for Victims of Crime (2015) and Ricciardelli (2018) also state that household burglary is also a prevailing issue within rural settings across the globe.

Crime Statistics Report (2016) by Nigeria's National Bureau of Statistics (NBS) highlights a total of 45,554 burglary cases reported in Nigeria in 2016. Of the total, 19,938 (which accounts for $43.76 \%$ of the total reported burglary crimes) took place in the South-Western part of Nigeria, which includes Lagos, Oyo, Ogun, Osun and Ondo. The same report states that Oyo state is ranked third in the incidence of burglary crime in South-Western Nigeria after Lagos (Nigeria's commercial hub and former federal capital territory) and Ondo state (the nation's oil-producing region). Oyo state is presently ranked $13^{\text {th }}$ in public order and safety out of the 36 states of the country (National Bureau of Statistics (NBS), 2016) and $6^{\text {th }}$ (Lagos, Abuja, Delta, Kano, Plateau, Ondo, Oyo, Bauchi, Adamawa and Gombe States) in the general crime rate data provided by National Bureau of Statistics (2016) (Oguntunde et al., 2018). In Nigeria, while not all cases of household burglary are reported, time-series evidence shows that household burglaries are increasing. This could be attributed to unplanned urbanisation of urban and peri-urban areas and unresponsive security personnel (Alemika \& Chuckwuma, 2005).

Studies by the United Nations Office for West Africa (UNOWA) (2007), Owusu et al. (2015) and Owusu (2016) reveal that a relationship exists between urbanisation, safety and level of security. These studies show that the negative effects of urbanisation, such as: sprawl, an increasing urban population, unchecked settlement, and housing density, have resulted in inadequate service delivery (policing and safety machinery) in certain areas. Determinant factors such as poverty, poor governance, lack of space orderliness, inefficient planning processes, weak service delivery and inadequate basic social amenities create a fear of crime and perceived insecurity among residents. Furthermore, this insecurity is a reflection of poverty and poor governance (Steffensmeier \& Allan, 1996; Cossman \& Rader, 2011; Wrigley-Asante, 2016).

One of the factors that residents consider when looking to settle is safety (Salleh, 2008; Mohit et al., 2010; Popoola et al., 2015). Household safety remains a conscious and sub-conscious criterion in habitation and resident location choice. Safety entails the absence of crime, an attack against life and property of a resident (Loewen et al., 1993; Bilsky, 2017; Meth \& Buthelezi, 2017). In ensuring safety, the literature identifies roles and responsibilities of government institutions, such as: the military, immigration authorities, customs officers and the judiciary, in maintaining public safety (Hopkins, 2007; Owusu et al., 2015; Bagson \& Owusu, 2016). However, formal institutions, especially in developing countries, have been considered ineffective and inefficient in these roles (Nganje, 2015; Cohen \& Felson, 2016; Elayah, 2016). 
The criminal externalities which pose a threat to the peaceful liveability of suburban and rural communities have resulted in "individualistic-policing" in the form of a number of unconventional crime fighting and response mechanisms, procedures and processes (Harris, 2001; Oteng-Ababio, 2016). John (2007) and Oteng-Ababio (2016) explain that local youth groups and vigilante groups, which are not legally considered as security agencies, are now championing the fight against crime making use of rules drafted and defined by them. The security of urban and rural areas requires extensive collaboration among various stakeholders in the settlement space at an individual, household and community level (Doyle, 2006; Lippert, 2009). This study aims to examine households and neighbourhoods' responses to household burglary in Ibadan, Oyo state, Nigeria. Furthermore, it strives to achieve security of lives and property which are being threatened in the country.

\subsection{The Study Area}

Ibadan, the capital city of Oyo State, is located in South-Western region of Nigeria, $128 \mathrm{~km}$ inland Northeast of Lagos and $530 \mathrm{~km}$ Southwest of the Federal Capital Territory (FCT), Abuja. During the colonial era, the city was considered the centre of administration for the Western Region of Nigeria (Fourchard, 2003). It is a prominent transit point between the coastal region and the areas to the north. According to the provisional census results of 2006, Ibadan has a population of 1,338,659 (National Population Commission (NPC), 2010) with an estimated population of 6,018,000 in 2018 (Dar-A1Handasah, 2018). It is the largest metropolitan area (with a land area of $3,123 \mathrm{~km}^{2}$ in Nigeria. Ibadan is made up of eleven local government areas (LGAs). Five of these local governments (Ibadan North, Ibadan South East, Ibadan South West, Ibadan North East and Ibadan North West) make up the city core while the remaining six local governments (Akinyele, Egbeda, Ido, Lagelu, Oluyole and Ona-Ara) are peri-urban and rural. The eleven LGAs now constitute what is now known as Ibadan region (see Figure 1). OgunleyeAdetona (2013) explains that Ibadan is a renowned and acclaimed city in West Africa and its reputation in terms of the rate of crimes committed by residents is almost of equal measure with its size.

Harries (1974) defines crime as a violation of law involving a victim and an offender which could be categorised as a crime against property and crime against a person. In line with this definition, Tomori (2010) reports that the increase in crime in Ibadan could be attributed to the city's transit routes and commercial activity centres. A significant number of inhabitants engage in on-street trading and hawking, with the city being characterised by poor accessibility, poor infrastructure, poverty and high crime rates (Dar-AlHandasah, 2018). Adepoju and Okunmadewa (2017) report that residents and households in Ibadan could be classified to be vulnerable to poverty owing to limited access to credit, low-income, poor educational qualification and large family size. To this development, Osowole et al. (2014) explain that poverty in Ibadan is beyond the principle of expenditure or ability to buy, but a combination of social, economic and political factors which limit the access of over $50 \%$ of the city's population to basic social amenities. 
Afon and Badiora (2018) report that burglaries in Ibadan can no longer be under-emphasised. They suggest that climatic season often dictates the occurrence of crime and that the risk of break-ins is stronger in the lowdensity neighbourhoods and rural areas. Vanguard (2011) reports that there was an increase in crime such as armed robbery, assassination and burglary in Ibadan. Adigun et al. (2016) similarly predicts that crime is expected to increase in Ibadan from 7,001 incidences of crime in 2008 to 12,512 in 2050. Modelling crime incidence, the same study identifies that between 2008 and 2050 residents of Ibadan between will experience 108-258 crime incidences per 1000 population.

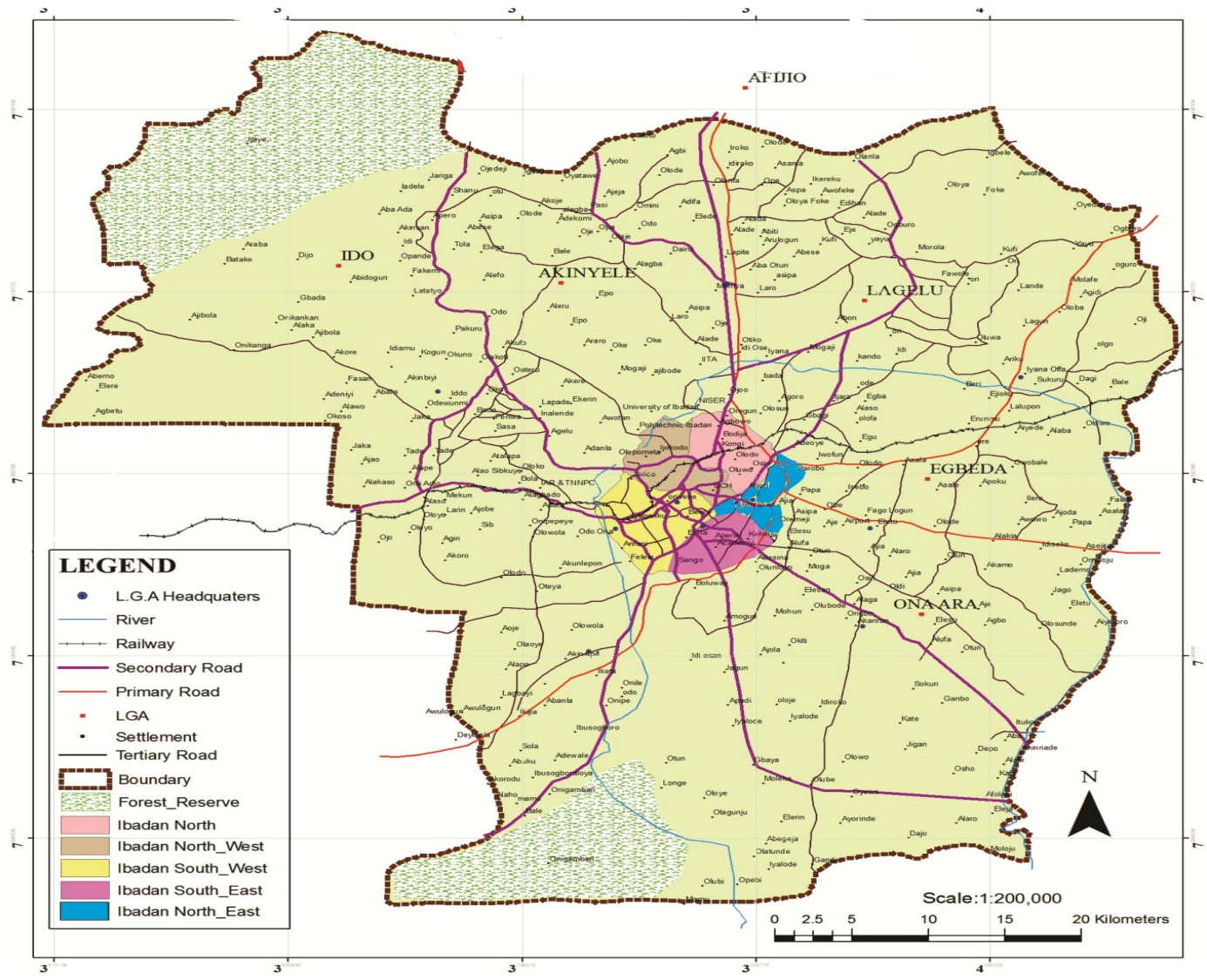

Figure 1: Ibadan Region

Source: Bureau of Physical Planning and Urban Development, Oyo State, 2018

\section{Methodology}

This study employs both quantitative and qualitative research approaches. The data retrieved through the quantitative approach of a structured questionnaire was used for both the descriptive (frequency tables) and inferential analysis (ANOVA). In-depth interviews conducted across the study area served as the qualitative data capturing instrument. The reason for a mixed approach is derived from the arguments of Ukoji and OkolieOsemene (2016) in their report on crime in Nigeria. The authors explain that a mixed approach in crime-related studies provides the researcher with a more individual explanation of the effect of the crime on the household. They argue that in the face of limited reliable and quality data on crime in Nigerian cities, researchers depend on qualitative data narratives of crime and victims to understand and complement quantitative data in such crime-related studies. 
This study uses a cross-sectional survey design as well as a multi-stage sampling technique. Sedgwick (2014) explains that the cross-sectional survey design is best suited to studies that make use of questionnaire and interview data capturing tools as it is quick, easy and cheap. Furthermore, once respondents are interviewed there is no need for follow-up. Along with this, Hemed (2015) states that this type of survey-design gives room for outcome estimations. Primary data was gathered through field observation, administration of household questionnaires in the selected residential neighbourhoods and unstructured interviews with selected individuals. Secondary sources of information which include records on burglary, crime and population from the Nigerian Bureau of Statistics, National Population Commission, private organisations and published literature, were used to explain the nature and rate of crime in the country. The study's fieldwork was conducted in the native language of the area, being Yoruba. Questions for both the quantitative and qualitative data were asked in the respondents' local dialect should the respondent not be able to respond to the questions in the English language.

\subsection{Quantitative Materials and Methods}

For this study the structured questionnaire is the quantitative data source and one of the primary data capturing tools. The study, using a household survey and structured questionnaire, was administered to each sampled household. The researchers consider a household as a group of people living under the same roof with a common financial source (which is usually the father or mother of the house). Questionnaires were administered to the household head. The household head in this regard is typically the father of the house and in single-parent households, the mother. In the situation where the head of household was not present, the most mature dweller in the household was sampled.

The structured questionnaire was aimed at capturing household information, such as: socio-economic characteristics (sex, age, income), housing characteristics (type of housing, nature of tenure, security measures), neighbourhood characteristics (type of neighbourhood, infrastructure available, security measures) as well as household and neighbourhood responses to burglary, was administered to the household heads in the selected residential buildings. The quantitative data was analysed using descriptive and inferential statistics (Analysis of Variance (ANOVA) at $p \leq$ 0.05 ). For this study, focus on respondents and household's sociodemographic characteristics was aimed at examining the vulnerability and exposure of households to burglary. The authors are of the view that burglary experiences and victimhood are across gender. Thus, the household characteristics will help to understand the authors' assumptions and views.

For effective representation across the study area, all the LGAs in the city were identified and categorised into urban or peri-urban local governments which are the primary administrative units (see Table 1) for proper representation of both LGA types (urban or peri-urban). The core five local governments are referred to as urban local governments, while the other six local governments are referred to as peri-urban local governments based on 
their locations within and outside the metropolitan area (Oluseyi, 2006; Bankole and Bakare, 2011; Adelekan, 2016).

From the identified eleven LGAs in Ibadan, one neighbourhood was randomly selected from each. This was done to promote generalised representation across the LGAs. The residential neighbourhoods are Moniya, Adegbayi, Iwo Road, Agbowo, Onireke and Mapo. Others are Oke Ado, Olorunsogo, Apete, Oyedeji and Oluyole Extension. In selecting streets and communities to sample within these randomly selected neighbourhoods, purposive-sampling was used taking into consideration factors such as easy accessibility, community status and popularity.

To arrive at the sample size for each LGA, the population of each LGA was considered as the target population and was used to arrive at the sample. One of the basic principles guiding the selection of sample size is that the smaller the population, the bigger the sampling ratio has to be for an accurate sample (Yusuf, 2003). Neuman (1991) opines that for a study population of 150,000 a $1 \%$ sample ratio is sufficient. Yusuf (2003) goes further and explains that in situations where the sample population is above 10 million, to achieve accuracy, a researcher may make use of $0.0025 \%$ sample size. Thus, for this study considering the Ibadan metropolitan population of 1,338,659 (National Population Commission (NPC), 2010) with an estimated population of $6,018,000$ estimate in 2018 (Dar-Al-Handasah, 2018) a sampling ratio of $0.0116 \%$ was considered suffice and was used to arrive at the sample size of 299. Thus, for this study, 299 household questionnaires were administered across the eleven LGAs in Ibadan. The sampling percentage was calculated to arrive at the sample size for each LGA using the population of LGAs.

Table 1: Sample Size

\begin{tabular}{|l|l|l|l|l|}
\hline & LGA & Categorisation & $\begin{array}{l}\text { Sampled } \\
\text { Neighbourhood }\end{array}$ & $\begin{array}{c}\text { Sample Size } \\
\mathbf{( 0 . 0 1 1 6 \% )}\end{array}$ \\
\hline 1 & Akinyele & Peri-urban/Rural & Moniya & 27 \\
\hline 2 & Egbeda & Peri-urban/Rural & Adegbayi & 10 \\
\hline 3 & Ibadan North-East & Urban & Iwo Road & 42 \\
\hline 4 & Ibadan North & Urban & Agbowo & 39 \\
\hline 5 & Ibadan North-West & Urban & Onireke & 19 \\
\hline 6 & Ibadan South-East & Urban & Mapo & 34 \\
\hline 7 & Ibadan South-West & Urban & Oke Ado & 36 \\
\hline 8 & Ona Ara & Peri-urban/Rural & Olorunsogo & 34 \\
\hline 9 & Ido & Peri-urban/Rural & Apete & 13 \\
\hline 10 & Lagelu & Peri-urban/Rural & Oyedeji & 19 \\
\hline 11 & Oluyole & Peri-urban/Rural & Oluyole Extension & 26 \\
\hline & Total & & & 299 \\
\hline
\end{tabular}

Sources: NPC (2010); Oluseyi (2006); Bankole \& Bakare (2011); Adelekan, (2016)

\subsection{Qualitative Materials and Methods}

For the qualitative data for this study, in-depth interviews were conducted for a total of twenty respondents. Convenience-sampling was used to select and interview household heads, while purposive-sample technique was employed to select and interview neighbourhood heads and neighbourhood security 
officers committee stakeholders. The interviewed household heads were different from the household heads administered questionnaires. Instances, where a household head, household dweller or neighbourhood dweller came (possibly to visit or to know what the survey was about) into the household when the questionnaires were being administered, such a respondent was interviewed to eliminate the bias of already having the foreknowledge of the questionnaire questions. The interviews were transcribed and analysed using content analysis. Field observations and open-ended questions were also employed to capture the data.

\section{Result Findings and Discussion}

\subsection{Socio-Economic Characteristics of the Respondents}

For this study, sex composition (presented Table 2) revealed that $51.2 \%$ of the respondents were male while $48.8 \%$ of the respondents were female. Gender has been identified as the main determinant of burglary experience (Steffensmeier \& Allan, 2002; Mullin \& Cherbonneau, 2011). Female interviewees reported greater instances of witnessing a burglary than men. The investigation revealed that men usually hide when burglars attacked at night. Answering to the reason for this, a female occupant has this to say:

"Burglary attacks are usually serious when burglars sight male occupant because their belief is that they may be vehemently resisted, and this may lead to death on both sides"

(Research Respondent, January 2018).

A female interviewee stated that some wives even encouraged their husbands to hide under beds, inside toilets or even to flee when they noticed the presence on armed burglars in the house. Another interviewee quickly pointed out that fleeing from the scene of attack may be dangerous. According to the latter, the man may sustain serious injuries when fleeing or may even be killed by burglars. A male interviewee recounts his ordeals when fleeing from a burglary out of a window:

"I landed in a drainage channel just besides the wall fence, and I had serious bone fracture and dislocation. I was there till the following morning when I was taken to University Teaching Hospital (UCH), Ibadan where I was admitted and received treatment for not less than six months"

(Research Respondent, January 2018).

The age structure of the respondents indicates $41.1 \%$ of respondents were less than 30 years, $48.7 \%$ were between 31 to 50 years while the remaining $11.1 \%$ were above 50 years (see Table 2). Going by the study respondents, $89.8 \%$ can be considered young as they are aged below fifty years. This study cannot state that its respondents have a history of engaging in burglary activities, but studies by Adebayo (2013); Chiedu et al. (2015); Nwankwo and OkolieOsemene (2016) suggest that crime is usually perpetrated among the less aged people who are still physically young. This is so as aged and females are considered more vulnerable to the act of burglary. 
While $60.2 \%$ of respondents were married, $28.4 \%$ were single. Also, $6.0 \%$ of the respondents were widowed, $3.7 \%$ were divorced, and $1.7 \%$ were widowers (see Table 2). Marital status determines the household size and occupancy ratio (Adepoju \& Okunmadewa, 2011; Adeniyi et al., 2016). The average household size in Ibadan is large ( 8 members) and this makes it a densely populated city. Owing to the high population, there is a tendency for burglary and any other social crime to take place (Shichor et al., 1979; John Howard Society of Ontario, 1999; Nolan, 2004; Algahtany et al., 2018; Coccia, 2018).

Table 2: Demographic Characteristics of Respondents

\begin{tabular}{|l|l|l|}
\hline Sex & No. of respondents & Per cent \\
\hline Male & 153 & 51.2 \\
\hline Female & 146 & 48.8 \\
\hline Total & 299 & 100.0 \\
\hline & & \\
\hline Age & No. of respondents & Per cent \\
\hline Less than 30 years & 123 & 41.1 \\
\hline 31 to 50 years & 143 & 48.7 \\
\hline Above 50 years & 33 & 11.1 \\
\hline Total & 299 & 100.0 \\
\hline & & \\
\hline Marital Status & No. of respondents & Per cent \\
\hline Single & 85 & 28.4 \\
\hline Married & 180 & 60.2 \\
\hline Widowed & 18 & 6.0 \\
\hline Divorced & 11 & 3.7 \\
\hline Widower & 5 & 1.7 \\
\hline Total & 299 & 100.0 \\
\hline & & \\
\hline Educational Status & No. of respondents & Percent \\
\hline No Formal Education & 16 & 5.4 \\
\hline Primary Education & 13 & 4.3 \\
\hline Secondary education & 57 & 19.1 \\
\hline Technical college Education & 13 & 4.3 \\
\hline National Certificate Education & 66 & 22.1 \\
\hline $\begin{array}{l}\text { Higher National Diploma and } \\
\text { Degree Education }\end{array}$ & 97 & 32.4 \\
\hline Post-graduate Education & 21 & 7 \\
\hline Modern Education & 16 & 5.4 \\
\hline Total & 299 & 100.0 \\
\hline & & \\
\hline & & \\
\hline & 67 & \\
\hline & & \\
\hline
\end{tabular}

Some of the respondents $(5.4 \%)$ had no formal education, and these were mainly people between the ages of 50-60 years, above $4 \%$ of respondents obtained primary school leaving certificate, $5.4 \%$ modern education, secondary school certificates (19.1\%), technical college certificate $(4.3 \%)$, National Certificate of Education (NCE) (22.1\%), Higher National Diploma (HND) and first-degree certificate (32.4\%) and post-graduate degrees (7\%) (see Table 2). Some of the idle youths and unemployed individuals engaged in burglary by intruding into the premises of the educated and working-class 
residents (i.e. teachers) when they have gone to work. A lack of education brings about the worst in the behaviour of a young person (Cowell, 2006; Monk, 2014; Osowole et al., 2014; Al-Qahtani, 2016; Kremer et al., 2016; Adepoju \& Okunmadewa, 2017). If the majority of Ibadan inhabitants can go to school, then there could be indirect effects on crime which may reduce the tendency of crime occurrence; as education has been reported to reduce social vices among people (Osowole et al., 2014; Adepoju \& Okunmadewa, 2017).

Table 3: Nature of Occupation and Income of Respondents

\begin{tabular}{|c|c|c|}
\hline Occupation & No. of respondents & Per cent \\
\hline Farming & 37 & 12.4 \\
\hline Private sector & 108 & 36.1 \\
\hline Public service & 85 & 28.4 \\
\hline Retiree & 10 & 3.3 \\
\hline Student & 37 & 12.4 \\
\hline Apprentice & 15 & 5.0 \\
\hline Unemployed & 7 & 2.3 \\
\hline Total & 299 & 100.0 \\
\hline $\begin{array}{l}\text { Monthly Income (1) (1USD to } \\
\text { 340) }\end{array}$ & No. of respondents & Percent \\
\hline Less than $\$ 10,000(\mathbf{\$ 2 9 . 4})$ & 81 & 27.2 \\
\hline 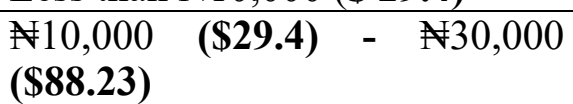 & 59 & 19.8 \\
\hline $\begin{array}{l}N 31,000 \quad(\$ 91.17) \\
(\$ 147.05)\end{array}$ & 78 & 26.2 \\
\hline 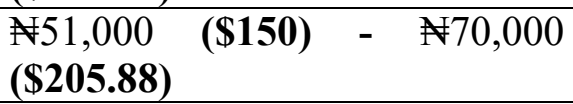 & 39 & 13.1 \\
\hline $\begin{array}{ll}\$ 71,000 & \mathbf{( \$ 2 0 8 . 8 2 )} \\
990,000(\$ 264.7)\end{array}$ & 28 & 9.4 \\
\hline $\begin{array}{l}\text { N91,000(\$267.64) - } ¥ 120,000 \\
(\mathbf{\$ 3 5 2 . 9 4 )}\end{array}$ & 11 & 3.7 \\
\hline Above 120,000 (\$352.94) & 3 & 1.0 \\
\hline Total & 299 & 100.0 \\
\hline
\end{tabular}

Ibadan and cities in Nigeria are characterised by informal private trading activities and street hawkers, many of whom are secondary school leavers and can be classified as educationally vulnerable (Adeagbo, 1997; Bogoro, 2016). As presented in Table 3,64.5\% of the total sample either engages in the public or private sector of the economy. It was identified that private jobs such as trading, teaching in private schools, barbing and all other sorts of private commercial activities made up the $36.1 \%$ of the sample that were employed in the private sector. The remaining $63.9 \%$ are government civil servants working in public schools, health officers in government hospitals, state and federal secretariats. From the interview, it was revealed that burglary mainly occurred when private and public-sector workers, students and farmers had left homes and gone to their different places of work. It can, therefore, be deduced that the sample, representing about $65 \%(64.5 \%)$ of the entire respondents sampled were mostly the victims of burglary. 
The survey presented in Table 3 indicates that the overwhelming majority of the respondents $(95.7 \%)$ are earning less 1 USD per day. This is not enough to cater for basic needs such as food, clothing and housing, let alone to secure homes with various security measures (Adepoju \& Okunmadewa, 2011; Tade $\&$ Aderinto, 2012). Therefore, they are always afraid of burglars. However, those residents earning relatively high incomes secure their housing units with some security measures such as private security, dogs and electric fencing which deters burglars (Badiora \& Afon, 2013; Badiora et al., 2017). Nevertheless, some burglars have special equipment and skills that allow them to break into secured houses (National Institute of Justice, 2007).

From the study, the evidence suggests that single women and low-income earners are the most vulnerable to burglary crime. Conventional wisdom states that crime perpetrators are opportunistic and cautious. Some studies have attributed the fear among females and the risk-taking nature of males as reasons for the higher number of crimes experienced by women (Fetchenhauer \& Buunk, 2005; Hirtenlehner \& Farrall, 2014). Likewise, high-income households have a variety of options regarding the best mechanism to prevent burglary crime both at an individual and neighbourhood level - a choice not available to the poor or low-income neighbourhood due to poverty (Pantazis, 2000).

\subsection{Housing Characteristics of Sampled Houses}

Evidence from Table 4 presents an array of various types of housing in the Ibadan area. The housing types include the Brazilian building which is commonly called face-to-face house or tenement building, flat apartment, traditional compound houses and duplex (7.7\%). Brazilian housing consists of between 6-12 rooms with a single entrance. It is a heterogeneous type of housing where all the single room users share a general sanitary facility. In many instances, residents of such rooms are not related but of various cultural backgrounds who reside together because it is the only accommodation they can afford, or it is close to their workplace. Field observations show that a flat can be a one, two, three, four or five-bedroom apartment, while a duplex is a private housing unit or apartment made up of 2-5 rooms which can be a single or double storey, or a building located side by side either detached or not from each other. A duplex is meant to house individual households and can have multiple exits and entrances.

The majority of the interviewees explained that people living in tenement buildings, flats and duplexes were the main targets of burglaries. The various avenues through which the burglars broke into these houses were through the windows, backdoors and rooftops. In a group interview an official of a private security outfit established the relationship between building type and burglary incidence. He said:

"Many of these face-to-face houses do not have gates; they [tenants] leave the door open due to a large number of individual occupants. Even an outsider can work in anyhow...so what the burglar needs to do is to monitor when they have all gone out and enter freely without any hindrance either through the front door or any of the windows... and many of them do not use traditional 
means [locally made charms] to secure their assets from theft...unlike the traditional compound buildings where charms can be found at the entrances. Some landlords also buried antiburglary crime charms under the ground...The charms were prepared to make the house unattractive to burglars"

(Research Respondent, January 2018).

Residents of the traditional compound housing type are less vulnerable to burglary crime. A traditional compound housing type is typically occupied by extended family and is characterised by a large expanse of land surrounding small huts and a homestead to form a family area around. Most households living in traditional compound houses have a large household size (8-12 members). Most of the households were made up of immediate nuclear family members, members of extended family, friends and colleagues, house helps and apprentices. Thus, there is always someone at home at a particular point in time. Residents observed that people living in traditional compound houses rarely experience burglary due to the presence of people in the house throughout the day.

Most of the traditional compound housing units can be found in the core areas of Ibadan. Adeli (2011) showed that residents in old areas of the city, where social unity is witnessed, felt more secure. Also, the windows of traditional compound housing units normally discouraged burglary crime, as they are usually small at 500x500mm, and hence are not wide enough to accommodate a burglar.

Table 4: Housing Characteristics

\begin{tabular}{|c|c|c|c|}
\hline \multicolumn{4}{|c|}{ Respondents' Tenure Status } \\
\hline & Nature of Tenure & No. of Respondents & $\%$ \\
\hline 1 & House-owner & 109 & 36.5 \\
\hline 2 & Tenant & 183 & 61.2 \\
\hline 3 & $\begin{array}{l}\text { Others } \\
\text { squatter) }\end{array}$ (Sharer, visitor, & 7 & 2.3 \\
\hline & Total & 299 & 100.0 \\
\hline \multicolumn{4}{|c|}{ Means of Accessibility to the House } \\
\hline & Means & No. of Respondents & $\%$ \\
\hline 1 & Footpath & 107 & 35.7 \\
\hline 2 & $\begin{array}{l}\text { Road (minor, major or } \\
\text { connector) }\end{array}$ & 192 & 64.3 \\
\hline & Total & 299 & 100.0 \\
\hline \multicolumn{4}{|c|}{ Housing Type } \\
\hline & Tуре & No. of Respondents & $\%$ \\
\hline 1 & Traditional compound house & 33 & 11.1 \\
\hline 2 & Brazilian (face-to-face) type & 130 & 43.4 \\
\hline 3 & Flat & 113 & 37.8 \\
\hline 4 & Duplex & 22 & 7.7 \\
\hline & Total & 299 & $\mathbf{1 0 0 . 0}$ \\
\hline
\end{tabular}

Table 4 reveals that $61.2 \%$ of the respondents were tenants, $36.5 \%$ were house-owners, and $2.3 \%$ were either sharers or squatters. Through openended individual conversations and field observations, it was found that most 
of the wives of house owners, popularly called "landlords", were engaged in home-based informal sector economic activities like home trading, neighbourhood hawking, and homeschooling for children. By engaging in these economic activities, women were able to keep watch on the house. In a group interview conducted with the wives of homeowners, a wife narrated her experience as follow:

"My husband built the shop for me in front of the house and encouraged me to be selling there... he thought this will give us an opportunity to look after our home and secure our assets.... and I am sure this has helped. Some houses that do not have shops in front of them or anyone at home during the day have been burgled at one time or the other. Some people in these houses have experienced daylight burglary when they were not around this year..."

(Research Respondent, January 2018).

While many interviewees believed that such houses could not be burgled during the daytime, others felt their occupants could still be robbed. A female tenant narrated her experience as thus:

"We were three at home when they [robbers] came to rob us in the house. Other people were not around, so the house seemed to be empty... When they [robbers] came, they pretended like visitors in order to enter the house, and immediately they entered they showed us weapons [cutlass and gun] they collected the little money we have, we couldn't shout or call for help...they left on a motorbike...before we came out, to shout for help they were gone..."

(Research Respondent, January 2018).

Most burglaries were committed during the day, most especially during the market days and on Sundays when the neighbourhoods are nearly deserted. Some of the wives of house owners have also fallen victim of two criminals another female interviewee noted:

"There was a day I wanted to go and buy goods for sale. I put my money on the table, two men came with a motorcycle popularly called 'okada', one of them alighted from the motorcycle and pretended to be a customer. He bought a good that costs only \#150. He kept on asking for the prices of other goods just to distract my attention from the wallet I put on the table. He also gave me, 1,000 note and while I was looking for change, that is, \$50, he took my wallet. When I gave him the change, they sped off. Immediately, they left, I noticed that they have taken my money, I hired a motorcycle, we pursued them. But we were unable to catch them. The incident constrained me to employ a sales girl"

(Research Respondent, January 2018).

The theory of crime which was originally formulated by Lawrence Cohen and Marcus Felson, states that predatory crime occurs when a likely offender and 
suitable target come together in time and place, without a capable guardian present (Centre for Problem-oriented Policing, 2018).

Burglary occurred mostly in houses that were accessed through footpaths, but some residents that live in houses that were connected by major roads also reported that they had experienced burglary in the past. Table 3 shows that $64.3 \%$ and $35.7 \%$ respondents accessed their homes through roads and footpaths respectively. The results of interviews conducted on selected residents showed that houses accessed by footpaths and minor roads were hot spots for burglary crimes. According to an interviewee, some of the burglars that were caught reside within the neighbourhoods or had informants who lived in the neighbourhoods. This confirms the observation made by Townsley et al. (2015) that the likelihood of household burglary is influenced by proximity to burglars' home and easy accessibility to elope from the scene.

\subsection{Perceived Causes of Burglary Crime, Residential Neighbourhood Security Mechanisms and Household Response to Burglary}

According to respondents administered the questionnaire, some of the perceived factors that account for increased burglaries are joblessness $(37.5 \%)$, poverty $(29.1 \%)$, laziness $(27.8 \%)$ and lack of parental care $(4.7 \%)$. According to an interviewee:

"The main cause of burglary in my community is joblessness amongst the youth. Frustrations of joblessness among tertiary institution graduates in the society makes them opt for burglary in order to survive while some graduates engage in armed robbery just to cater for their needs and to meet up with their working-class counterparts."

(Research Respondent, January 2018).

McNamara (1968) states that irrespective of the acclaimed nature of security, any nation that sought security in the face of acute unemployment, poverty, low technological development, hunger and poor infrastructure has a false sense of security. The issue of unemployment has enhanced the engagement in social vices such as drug abuse. The use of drugs among the youths also aggravates criminal tendency. According to an interviewee:

"The use of drugs such as tramadol and syrups containing codeine make them high and more invasive."

(Research Respondent, January 2018).

Most of the youths depend on the use of Tramadol before engaging in criminal activities (Amali et al., 2017). Both drugs have just been banned in Nigeria, but some patent medicine shops are still selling these drugs, another interviewee observed. Farrell and Sullivan (2004) found out that witnessing violence also predicted subsequent increases in drug use. More so, the lack of integration of crime prevention strategies within comprehensive city planning practices is a factor in facilitating opportunities for urban crime (Fester, 2015; Oladosu et al., 2015; Chiodi, 2016; Ghani, 2017). Fester (2015) and Oladosu et al. (2015) highlight that city planners must efficiently manage space, 
reduce crime displacement in space, improve urban design, apply development control and improved building planning to curtail crime.

In the residential neighbourhoods surveyed, various security infrastructures were available. Neighbourhood restriction mechanisms aimed at preventing burglary include road bumps, gated streets and neighbourhood security checkpoints. Few gated communities or neighbourhoods exist in the study area, and these include the Government Reservation Areas (GRAs) at Agodi, Jericho and Onireke, private residential estates at Ring Road, Akobo and Iwo road. They are mostly occupied by medium and high-income earners.

The gated communities of the non-poor are characterised by high wall fences and gates that are manned by security personnel 24 hours a day. Motorcycles are not allowed to enter these communities because most of the perpetrators of urban crimes use them. Some neighbourhoods that are inhabited by lowincome groups are not fenced but have low gates at their entrances. These gates are not operated by security personnel and are open between 5am and $11 \mathrm{pm}$. It was observed in the course of conducting interviews with the residents that burglary rarely occurred in gated neighbourhoods but often occurs in non-traditional, non-gated neighbourhoods that constitute slums in semi-urban LGAs. Certain studies (Landman, 2000; Landman \& Schönteich, 2002; Atkinson et al., 2004; Breetzke et al., 2014) have also noted that that gated neighbourhoods experience less crime when compared to communities without gates.

De Rango (2001) identifies this trend of gating for security as a reflection of the income and status of neighbourhood dwellers. She argues that societal neighbourhood segregation resulting from gated communities are not a deliberate and conscious effort of high-income earners but rather a structural reflection of the society's unconscious arrangements. Liotta and Miskel (2014) suggests that insufficient infrastructure for the growing residential population breeds discontent among urban dwellers, leading to high crime rates, as visibly seen in growing megacities such as Karachi, Rio de Janeiro and Lagos.

Going by the evidence presented in Table 5, it was observed that the rate of burglaries in the peri-urban and rural LGAs (53 homes) is higher than the urban LGAs (40 homes). Ogboi and Eze (2013) asserted that the level of safety differs among urban residential neighbourhoods, especially between inner city and peri-urban areas. This is as a result of unplanned development, in the form of sprawl and high population movement that has marked new areas (NPC, 2010; Lasisi et al., 2016). These aspects make it easier for burglars to invade their premises. Furthermore, some security infrastructure such as police posts or police stations, good roads, street lights and other security programmes that normally present in the urban core neighbourhoods are not present. Examples of these are "operation burst" (security arrangement that comprises of officers of The Nigerian army, The Nigerian Police and the Nigeria Security and Civil Defence Corps by Oyo State government to tackle menaces and crime in the state with focus on the city), and the "seven cities" programme (a highway security initiative by The Nigerian Police to protect major highways across the state) which are rarely 
operated in peri-urban and rural areas, thereby making the residents vulnerable to burglars and other criminal activities.

This aligns with the views of, and confirms the observation made by, Cebulak (2004) and Marshall and Johnson (2005) that peri-urban and rural areas are characterised by increased criminality. Cebulak (2004) states that post 1991 a steady increase in crime in rural areas contrasts the urban crime decline between the years 1966 and 1991. Marshall and Johnson (2005) also report that the limited rural crime literature is the reason why scholars believed that crime is minimal in rural areas. Similarly, Adewale (2015) states that rural areas in Ibadan are now characterised by increased crime. Field observations reveal that many of these rural dwellers are migratory dwellers who migrate from rural LGAs where their houses are located to an urban area where their jobs and offices are located. Many leave their homes for as early as 7am and don't return until $6 \mathrm{pm}$.

Table 5: Burglary Experience Among Respondents According to LGA

\begin{tabular}{|l|l|l|l|}
\hline \multirow{2}{*}{$\begin{array}{l}\text { Burglary } \\
\text { Experience }\end{array}$} & \multicolumn{2}{|c|}{ Residential Location } & Total \\
\cline { 2 - 4 } & Urban LGA & $\begin{array}{l}\text { Suburban/Rural } \\
\text { LGA }\end{array}$ & \\
\hline Burgled & 40 & 53 & $93(31.1 \%)$ \\
\hline Not burgled & 113 & 93 & $206(68.9 \%)$ \\
\hline Total & 153 & 144 & 299 \\
\hline
\end{tabular}

Most of the houses (113) that have never been burgled can be found in the urban core areas. Impoverished neighbourhoods in the core areas are less vulnerable to burglary than in the peri-urban interface of metropolitan Ibadan. The assertion of Ogboi and Eze (2013) does not tally with this finding. These authors argue that wealthy neighbourhoods rank higher than poor areas in safety, while poor inner city neighbourhoods typically suffer from high crime. A rich neighbourhood house owner commented:

"My concern isn't the money spent on these security facilities [private security, dogs and fencing] my main interest is the security of my family and my entire assets whether I am at home or not..."

(Research Respondent, January 2018).

The findings of this study also contradict the observation made by Ross (2000) that residents of poor neighbourhoods in USA had high levels of fear of being victimised and injured yet out of necessity they walked more than residents of wealthy neighbourhoods. In the study area, high levels of fear of being victimised and injured are associated with the "area boys". These "area boys" are a group of locally organised gangs of street boys that mainly live on the road, abandoned properties and bushes and are usually armed with crime instruments such as cutlass, knives, broken bottle and sometimes locally made guns.

The intensity of crime in the peri-urban areas has effects on residential relocation and property value, according to some residents interviewed. There were cases where several tenants have relocated to other places in the core 
areas, especially after a burglary. Some landlords have also relocated to their compound houses in the core areas of the city because of burglary. One of the interviewees opined that:

"Most of the houses in his area are occupied by owners and where there are tenants, they usually pay low rent. Some house owners even encouraged tenants to live with them without paying rents."

(Research Respondent, January 2018).

Some residents believe that houses occupied by several people are not attractive to burglars. According to Philip (2008), the fluctuation of crime has a considerable effect on residential location and property values.

ANOVA was used to determine variations in burglary crimes committed among high, medium and low residential neighbourhoods. Analysis of data confirmed the research hypothesis which says: burglary crimes committed differ significantly among residential neighbourhoods $(\mathrm{F}=3.012)$ (see Table 6). This is so, owing to the status of the house owner, demographic characteristics of households, the neighbourhood security measures and installations put in place. This is also a pointer towards the increased cases of reported crime along the rural LGAs when compared with the urban LGAs. From field observation, sparse distributions of high-income housing across the rural/peri-urban LGAs which are often attractive to the burglar were seen. Some peri-urban LGAs are moving towards high-density populations, and with that the rate of burglary is now also on the increase. Nonetheless, the urban LGAs are reported to have been burgled more than peri-urban areas, as most residential homes with the urban LGAs have been built over the years and might have been burgled over time compared to a rural home that are not a resultant effect of urbanization.

It should be noted this study did not distil the spatial housing density arrangement within rural area. As observed, some rural communities within the rural LGA can be said to be of high density and wealthy house owner as against a rising trend of housing density from low to medium and traces of high density in some neighbourhoods. This argument suggests the need for a future purposive investigation of burglary across high-density neighbourhood within the rural and urban LGAs and burglary incidence in low-density neighbourhoods in rural and urban LGAs.

Table 6: ANOVA of Burglary Crime Committed Among Residential Locations

\begin{tabular}{|l|l|l|l|l|l|}
\hline $\begin{array}{c}\text { Type of residential } \\
\text { location }\end{array}$ & $\begin{array}{c}\text { Sum of } \\
\text { Squares }\end{array}$ & Df & $\begin{array}{c}\text { Mean } \\
\text { Square }\end{array}$ & F & Sig. \\
\hline Between Groups & 0.750 & 1 & 0.750 & 3.012 & 0.084 \\
\hline Within Groups & 73.432 & 295 & 0.249 & & \\
\hline Total & 74.182 & 295 & & & \\
\hline
\end{tabular}

The relevance of public-private partnership in fighting crime, as against the formal role of the police to fight crime has been reinstated (The Centre International de Formation des Autorités et Leaders/International Training 
Centre for Authorities and Leaders (CIFAL) \& Boisteau, 2006). Frost and Sullivan (2012) suggest that the approach of private/public partnership and cooperation in tackling the security challenges in residential neighbourhoods promote urban security and safety. Ogboi and Eze (2013) state that national response to the growing threats of crime and the inability of the police to provide adequate protection has led individuals, communities and businesses to use the services of private security and vigilante groups.

The vigilante groups, according to $39.5 \%$ of respondents, were the most effective security operatives in Ibadan, followed by the night watchmen $(13.4 \%)$ and gated community $(0.3 \%)$. Residents organised themselves into neighbourhood self-protection groups (vigilante groups) in order to ensure neighbourhood security. During an interview with a civil servant residing in one of the private residential estates, it was revealed that decisions on what security mechanisms to adopt in a neighbourhood is arrived at during the community or neighbourhood meetings. The interviewee observed:

"We [estate residents] agreed at one of our meetings [landlord meetings] not to allow okada people to enter into the neighbourhood again...owing to continuous report that the burglars make use of the bike when eloping the scene of robbery."

(Research Respondent, January 2018).

Members of Oodua People's Congress [OPC] (an indigenous security group) were also said to be relatively efficient at apprehending burglars. Security fee payment included in the land-use charge has just been implemented by the Oyo State Government along with awareness programmes for citizens of the state, especially those residing in the capital city-Ibadan. Recognising the role of diverse actors and stakeholders in enhancing community safety and the prevention of crime has led to various agencies advocating for the implementation of national policies that will help reduce and prevent crime. These include cooperation and partnerships with the corporate sector to prevent the act of insubordination of crime and take action to increase the likelihood that offenders will be apprehended.

Excluding neighbourhood security mechanisms, individual households also rely on various security mechanisms and install various security infrastructures depending on their status. The survey results presented in Table 7 indicates that $33.1 \%$ of the sampled respondent use dogs as the primary security measure on their premises, $19.7 \%$ had burglary iron proof bars fitted homes, $10.4 \%$ made use of closed-circuit security systems, security guards $(9.4 \%)$, security-flood lighting $(1.3 \%)$, alarm systems $(0.3 \%)$ and spiritual security $(24.7 \%)$. A further $1.0 \%$ of the sampled respondents refused to answer the question pertaining to security measures adopted at home. This could be inferred that they do not have any of the security measures available in their various residences.

Those who believed in spiritual security considered traditional approaches to curbing burglary and other crimes were more effective than the so-called western security measures. In an interview with a traditional chief in Apete, Ido LGA, it was revealed that: 
"My house has never and will never be burgled, I employ what my ancestors use in those days (indigenous spiritual power) to protect my house from robber."

(Research Respondent, January2018).

He expressed that he had never experience burglary and that he did not have any modern security measures in place. According to him, a traditional power attached to the entrance of his compound deters burglars from entering his premises. He went further to explain that he does not close his main entrance door during the day or at night even when nobody is around. A traditional city like Ibadan mostly adopts traditional ways of preventing burglary because the inhabitants of the city believe in traditions even when they are educated and religious. Some of these inhabitants still hold on to their indigenous identities. Suburban areas also adopt these traditional approaches. They consider this traditional/spiritual security mechanism more effective than the conventional means or even the Nigerian Police.

From the sampled households, $64 \%$ of respondents claimed that the Nigerian Police were not effective in curbing crime in their neighbourhoods as residents preferred the intervention of vigilante groups with guns (locally made). Observation revealed that this assertion is owed to the uneven distribution of police stations and inadequate police personnel in the suburban and rural LGAs. A resident summarised the inefficiency of the police officers:

"We have less than five police officials at the police station in my community...out of this five, it is not all of them that comes to work every day...even if they come, they don't even have a vehicle to respond to calls by the residents and not all of them can handle a gun."

(Research Respondent, January 2018).

Table 7: Household and Residential Neighbourhood Security Measures

\begin{tabular}{|l|l|l|l|}
\hline \multicolumn{4}{|l|}{ Security measure in the Neighbourhood } \\
\hline & Measure & No. of Respondents & $\%$ \\
\hline 1 & Private night watchmen & 40 & 13.4 \\
\hline 2 & Gates & 1 & 0.3 \\
\hline 3 & Collective vigilante groups & 118 & 39.5 \\
\hline & Total & $\mathbf{2 9 9}$ & $\mathbf{1 0 0 . 0}$ \\
\hline & Available Security Measure in Individual House \\
\hline & Measure & No. of Respondents & $\%$ \\
\hline 1 & Guard/Security Dogs & 99 & 33.1 \\
\hline 2 & Security guards & 28 & 9.4 \\
\hline 3 & Security Alarm system & 1 & 0.3 \\
\hline 4 & Closed Circuit system & 31 & 10.4 \\
\hline 5 & Burglary proof & 59 & 19.7 \\
\hline 6 & Spiritual / traditional security & 74 & 24.7 \\
\hline 7 & Others (No response) & 3 & 1.0 \\
\hline & Total & $\mathbf{2 9 9}$ & $\mathbf{1 0 0 . 0}$ \\
\hline
\end{tabular}




\section{Discussion and Recommendation}

House burglary is one of the most common crimes in Ibadan which is of great concern to the general public. It therefore needs urgent attention. Crime remains unevenly distributed among residential neighbourhoods; spatial studies of burglary crimes show that certain neighbourhoods experience burglary crimes more frequently than others.

Every city has a unique blend of insecurity challenges and need individualised strategies to tackle the issue of burglary. There is a need to further encourage the coverage of security programmes such as "operation burst" and "seven cities" to reach peri-urban and rural areas. Likewise, the training of police in the handling of weapons and increased responsiveness among the officers should be encouraged.

According to the Security and Defense Agenda in Europe (2011), urban residential neighbourhood security requires a comprehensive strategy that spans the police and judiciary as well as other administrations at local and international levels in addressing internal and external insecurity. Kwaja (2016) states that the privatisation of security in residential neighbourhoods has significant implications for an ineffective and democratically unaccountable public security sector. However, the proliferation of informal security providers such as vigilante groups should be controlled and wellmanaged so that they do not become a potential security challenge. Thus, there is the need to adopt guided privatisation in the area of security so that the informal security groups are subjected to the control of the Nigerian Police.

As identified in the study by $64 \%$ of sampled household respondents that the Nigerian Police is considered ineffective in their discharge of duties, coupled with the assertion of interview respondents that 5 police officials are available with only few able to handle weapons such as guns. This study therefore reinstates that to achieve security of lives and property, there is the need to improve public security investment in the form of the police stations and increased police personnel in the available police stations in the city. Security facilities such as police posts, checkpoints, and gates as well as personnel are to be adequately provided by the Federal (through the Nigerian Police Force headquarter) and State Governments for those people in suburban neighbourhoods. The government should give urban residential neighbourhood security enough attention or allow this to remain a local matter. Within Nigeria, repositioning the Nigerian Police, introduction of state police, establishment of more police stations, capacity building for the Nigerian Police, improved police welfare and the provision of conventional crime-fighting instruments are some of the issues that are raised towards the fighting of crimes such as burglary (Otu, 2004; Adefi \& Achor, 2013; Omolola \& Olaitan, 2013; Agwanwo, 2014; Mathias, 2016). This study is of the view that duplication of security operative is a reflection of failed or failing public security mechanism.

UNHabitat (2007a) opined that poor urban design and planning have increasingly been cited as playing a role in the shaping of urban environments that put citizens and property at risk. The report further states that the physical 
fabric and layout of cities have a bearing on the routine movements of offenders, victims and opportunities for crime. Neighbourhood planning and good house design remain a means through which burglary can be prevented. According to UNHabitat (2007b), physical designs such as gated communities, low-walls or fences, set-backs, cul-de-sacs and management of the built environment play a role in facilitating or diminishing opportunities for crime and violence. The construction of high perimeter walls and fences should be discouraged. Timberlake (2015) states that residential neighbourhood security can be achieved through low perimeter walls and fences and elevation that creates natural, unobtrusive barriers. Likewise, the use of easily accessible materials such as broken bottle and dogs must be maximised in the quest to be secure. The installation and operation of CCTV camera in strategic locations is also important. This is to reduce burglary crime and increase public safety in residential neighbourhoods.

The study researchers identify collective policing as a means of preventing neighbourhood burglaries. Individuals and unfamiliar faces that are regularly seen during odd hours of the day should be approached carefully. Communities should question suspicious characters around their compounds and promptly report any crime to the police. Likewise, the erection of shops with a trader in front of the houses can help curtail the frequency of burglaries as this will serve as a signal that someone is around, and if need be the person can easily call for help from the police if available in such an area. The study also recommends daytime patrol by police and local security groups when the owners may not be around. This will help control the cases of burglary when household residents are not around and clarify the argument that the young unemployed are potential perpetrators of burglary in the area.

The study also identifies the need for improved prevention of over-thecounter sales of drugs without pharmaceutical approval. Data collected from respondents of this study suggests that there is a strong relationship between drug users and burglary crime. The study identifies the need for rigid control of unapproved pharmaceutical stores and local alcohol stores in efforts towards reducing access to these substances. Likewise, agencies such as the Pharmaceutical Society of Nigeria (PSN), Nigerian Drug Law Enforcement Agency (NDLEA) and National Agency for Food and Drug Administration and Control (NAFDAC) must monitor the easy access to illicit drugs. The study advocates for improved investment in social and community works by both government, private agencies and Non-Governmental Organisations (NGOs) for jobless youths and "area boys" that needs rehabilitation. The researchers identify the need to encourage apprenticeships for youths, as this will help limit social vices and generate menial incomes for survival. Communities must realise that limiting the exposure of the youth to drugs and harmful social vices is dependent on them. Communities must limit or prevent the sales of drug (codeine, tramadol, marijuana) within the neighbourhood through the introduction of strict rules that prevents such. Neighbourhood outreaches and awareness of the adverse effect and outcome of illicit drug use should take place in the schools within the communities. As illustrated by Rhew et al. (2011) in their study on drug-use risk among rural adolescent, rural youth exposure to drugs is associated with residential location and school attendance. The study states that rural dwelling youths are more likely to engage in illicit drug use than urban dwelling youths. Soul 
City Institute of Drug Abuse South Africa (undated) states that reducing the effect of drug abuse should focus on reducing drug supply, drug demand and harm.

Finally, increased investment in security mechanism calls for public-private, one of which is the newly introduced security charges introduced along with the land-use charge by the Oyo state government.

\section{Conclusion}

In the face of urbanisation and suburbanisation, social ills arise. There are numerous negative effects of unplanned urbanisation that are beyond the city enclave as dwellers in rural areas are now also experiencing its manifestationhousehold burglary.

Within the Nigeria state, the reality of suburbanisation can no longer be ignored. Planning specialists and advocates for city security must not propose an all-inclusive settlement which includes the peri-urban and rural areas. The era of continuous investment of security apparatus must now look towards adapting security apparatus that aligns with the spatial arrangement of rural areas too. The issue of spatial arrangement has thus limited the complete representation of the rural areas and its effective classification (high, medium and low density). It has become evident as a result of field observations that the perception of rural household poverty might not be entirely true as migrant households (urban high- and medium-income earners who have homes built in rural or peri-urban areas) are on the increase within the rural areas. Also, the definition of poverty remains a subject that needs to be carefully investigated as the study didn't take into consideration the household expenses or the housing structure of the low-income (less than 1USD per day) earners; as the \$1 per day poverty definition is subjected to externalities such as exchange rate, payment of salary and the relationship between individual educational qualification and income.

As against a longitudinal approach, this study employed a cross-sectional survey. The limitation of this is that the rate of incidence of neighbourhood or household burglary crime will not be well-documented, especially for household responders who are not the house owners, but tenants. This study also was limited as it did not take into consideration the years of occupancy of the respondents both within the neighbourhoods and also in the house sampled.

The study did not investigate the origin of drug use as identified by the respondents. The argument that burglars are drug users was not well investigated. Likewise, the study did not establish if any burglars were caught in the act of burglary and if the burglars where dwellers within the neighbourhoods. These aspects are imperative in establishing the association between the neighbourhood sales of drugs and engaging in the act of burglary by dwellers within the neighbourhood; or if the drug dealers are located outside the communities of study.

Households are typically lifeless zones during the working hours (between $7 \mathrm{am}$ and $6 \mathrm{pm}$ ) when occupants are not at home. The study also did not query 
if there are youths at home during these hours, and if there are, what the youths do. This is important towards understanding household approaches towards discouraging their adolescents from loneliness, peer-pressure to engage in burglary, and also what households do to prevent their adolescents at home from been exposed to crime. This will proffer a clearer understanding of the proposal for youth empowerment in the study area.

\section{References}

Adeagbo, D. (1997). Physical and Socio-Economic Impact of Street Trading: Case Study of Ibadan. Nigerian Institute of Social and Economic Research (NISER): Ibadan, Nigeria:

Adebayo, A. (2013). Youths' Unemployment and Crime in Nigeria: A Nexus and Implications for National Development. International Journal of Sociology and Anthropology, 5(8), pp.350-357.

Adefi, O.M. \& Achor, A.J. (2013). Re-awakening the State Police Controversy in Nigeria: Need for a rethink. International Journal of Asian Social Science, 3(11), pp.2307-2314.

Adelekan, I.O. (2016). Ibadan City Diagnostic Report. Working Paper \#4, Urban African Risk Knowledge. [Online]. Available at: https://www.urbanark.org/sites/default/files/resources/Urban\%20AR KIBADAN\%20CITY\%20DIAGNOSTIC\%20REPORT07032016\% $255 \mathrm{~b} 2 \% 255 \mathrm{~d} \% 20 \% 20 \mathrm{IOA} . p d f$ (Accessed $18^{\text {th }}$ May 2017).

Adeli, S. (2011). Security in Urban Places in Enhancing Urban Security and Safety in Nigeria Through Physical Planning and Management, Annual Conference Proceedings of the Nigerian Institute of Town Planners (NITP), p.93.

Adeniyi, A.B., Daud, A.S., Amao, O. \& Omotayo, A.O. (2016). Determinants of Rural Women's Livelihood in Ibarapa North Local Government Area of Oyo State, Nigeria. Journal of Human Ecology, 56(1-2), pp.84-90.

Adepoju, A. O. \& Okunmadewa, F.Y. (2017). Households' Vulnerability to Poverty in Ibadan Metropolis, Oyo state, Nigeria. Journal of Rural Economics and Development, 20(1), pp.44-57.

Adewale, J. G. (2005). Socio-economic Factors Associated with Urban-rural Migration in Nigeria: A Case Study of Oyo State, Nigeria. Journal of Human Ecology, 17(1), pp.13-16.

Adigun, F.O., Adeibu, A.A. \& Abolade, O. (2016). Predictive modelling of crime in selected Nigerian cities. Advances in Social Sciences Research Journal, 3(6), pp.121-129.

Afon, A. \& Badiora, A. (2018). The Dynamics of Crime Opportunities: Evidence from Weather Conditions and Spatial Pattern of Residential Neighbourhood in Ibadan, Nigeria. Papers in Applied Geography, 4(1), pp.1-20.

Agwanwo, D.E. (2014). State Policing and Police Efficiency in Nigeria. Research on Humanities and Social Sciences, 4(25), pp.165-173.

Alemika, E. \& Chuckwuma, I. (2005). Criminal Victimization and Fear of Crime in Lagos Metropolis, Nigeria, CLEEN Foundation Monograph Series; CLEEN Foundation Monograph Series II, pp.135. Available at: 
http://new.cleen.org/LAGOS\%20CRIME\%20SURVEY.pdf (Accessed 20 ${ }^{\text {th }}$ March 2017).

Algahtany, M., Kumar, L., Barclay, E. \& Khormi, H. (2018). The Spatial Distribution of Crime and Population Density in Saudi Arabia. Crime Prevention and Community Safety, 20(1), pp.30-46.

Al-Qahtani, N.S. (2016). The Undesirable Behaviours of Students in Academic Classrooms, and the Discipline Strategies Used by Faculty Members to Control Such Behaviours from the Perspective of the College of Education Students in King Saud University. International Education Studies, 9(3), pp.197-211.

Amali, S.E., Moshood, I. \& Iliyasu, M.B. (2017). Impact and Implications of Youth Involvement in Urban Gangs: A Case Study from Nasarawa, Kano State, Nigeria. Acta Criminologica: Southern African Journal of Criminology, 30(5), pp.150-169.

Anderson, H.A. (2011). From the Thief in the Night to the Guest Who Stayed Too Long: The Evolution of Burglary in the Shadow of the Common Law. Indiana Law Review, 45, pp.629-668.

Atkinson, R., Blandy, S., Flint, J. \& Lister, D. (2004). Gated communities in England. Office of the Deputy Prime Minister: London.

Badiora, A.I. \& Afon, A.O. (2013). Spatial pattern of Crime in Nigerian Traditional City: The Ile-Ife Experience. International Journal of Criminology and Sociological Theory, 6(3), pp.16-28.

Badiora, A.I., Afon, A.O. \& Dada, O.T. (2017). Seasonality of Violent and Property Crime in Nigeria: Some Preliminary Findings. International Journal of Criminology and Sociological Theory, 10(2), pp.1-23.

Bagson, E. \& Owusu, A. (2016). Securing the Urban Space: On whose terms? Insights from Poverty and Crime Baseline Survey in Tamale, Ghana. Ghana Journal of Geography, 8(1), pp.124-147.

Bankole, M.O. \& Bakare, H.O. (2011). Dynamics of Urban Land Use Changes with Remote Sensing: Case of Ibadan, Nigeria. Journal of Geography and Regional Planning, 4(11), pp.632-64.

Bilsky, W. (2017). Fear of crime, personal safety and well-being: A common frame of reference. Keynote at the 12th European Conference on Psychology and Law September 14-17, 2002. Leuven, Belgium Universitäts-und Landesbibliothek Münster. Available at: https://www.researchgate.net/profile/Wolfgang_Bilsky/publication/3 17546347_Fear_of_Crime_Personal_Safety_and_WellBeing_A_Co mmon Frame of Reference/links/593f0398458515a621652cf1/Fear -of-Crime-Personal-Safety-and-Well-Being-A-Common-Frame-ofReference.pdf (Accessed $2^{\text {nd }}$ August 2018).

Bogoro, A.G. (2016). Effects of Street Trading on Urban Areas in Nigeria. Global Advanced Research Journal of Management and Business Studies, 5(2), pp.51-56.

Breetzke, G.D., Landman, K. \& Cohn, E.G. (2014). Is it Safer Behind the Gates? Crime and Gated Communities in South Africa. Journal of Housing and the Built Environment, 29(1), pp.123-139.

Cebulak, W. (2004). Why Rural Crime and Justice Really Matter. Journal of Police and Criminal Psychology, 19(1), pp.71-81.

Centre for Problem-oriented Policing. (2018). Step 8: Use the Problem Analysis Triangle. Arizona State University. [Online]. Available at: https://popcenter.asu.edu/content/step-8-use-problem-analysistriangle (Accessed 30 ${ }^{\text {th }}$ November 2017). 
Chiedu, A., Solaja, O. \& Olawunmi, S. (2015). Perception on the Trend and Patterns of Youth Criminality in Ibadan South-western, Nigeria. African Journal for the Psychological Study of Social Issues, 18(1), pp.72-83.

Chiodi, S. (2016). Crime Prevention Through Urban Design and Planning in the Smart City Era: The Challenge of Disseminating CP-UDP In Italy: Learning from Europe. Journal of Place Management and Development, 9(2), pp.137-152.

CIFAL (Centre International De Formation des Autorités Et Leaders/International Training Centre For Authorities and Leaders) \& Boisteau, C. (2006). Building Communities: Urban Planning and Security Policies. EPFL, Ecole Polytechnique de Lausanne, ENAC, Faculty of the Natural, Architectural and Built Environment, INTER, Institute of Territorial Development, LaSUR, Laboratory of Urban Sociology. [Online]. Available at: https://www.unitar.org/dcp/cifalnetwork/cifal-centres (Accessed $4^{\text {th }}$ July 2018).

Coccia, M. (2018). The Relation Between Terrorism and High Population Growth. Journal of Economics and Political Economy, 5(1), pp.84104.

Cohen, L.E. \& Felson, M. (2016). Social Change and Crime Rate Trends: A Routine Activity Approach (1979). In Classics in Environmental Criminology. M. Andresen, P. Brantingham \& J. Kinney (eds). Boca Raton: CRC Press. pp.203-232. [Online]. Available at: https://www.taylorfrancis.com/books/e/9781439817803/chapters/10. 4324\%2F9781439817803-12 (Accessed 2 ${ }^{\text {nd }}$ August 2018).

Cossman, J.S. \& Rader, N.E. (2011). Fear of Crime and Personal Vulnerability: Examining Self-Rated Health. Sociological Spectrum, 31(2), pp.141-162.

Cowell, A.J. (2006). The Relationship Between Education and Health Behaviour: Some Empirical Evidence. Health Economics, 15(2), pp.125-146.

Dar-Al-Handasah (2018). Ibadan City Master-plan. Available at: www.ibadanmasterplan.com (Accessed $2^{\text {nd }}$ August 2018).

De Rango, K. (2001). Discrimination and Segregation in Housing, W.E. Upjohn Institute for Employment Research, USA Press: USA.

Doyle, A. (2006). An Alternative Current in Surveillance and Control: Broadcasting Surveillance Footage of Crimes in The New Politics of Surveillance and Visibility. K.D. Haggerty \& R.V. Ericson (eds). University of Toronto Press: Toronto, pp.199-224.

Elayah, M. (2016). Lack of Foreign Aid Effectiveness in Developing Countries Between a Hammer and an Anvil. Contemporary Arab Affairs, 9(1), pp.82-99.

Farrell, A.D. \& Sullivan, T.N. (2004). Impact of Witnessing Violence on Growth Curves for Problems Behaviour Among Early Adolescents in Urban and Rural Setting. Journal of Community Psychology, 32, pp.505-525. DOI:10.1002/jcop.20016

Fester, R.N. (2015). Crime Prevention Through Spatial Planning: The Case of Harare, Khayelitsha. Master's Thesis, University of Cape Town, Cape Town, South Africa. Available at:

https://open.uct.ac.za/bitstream/handle/11427/18204/thesis_ebe_201 5 fester_ryan nicholas.pdf; sequence $=1$ (Accessed $3^{\text {rd }}$ August 2018). 
Fetchenhauer, D., \& Buunk, B.P. (2005). How to Explain Gender Differences in Fear of Crime: Towards an Evolutionary Approach. Sexualities, Evolution \& Gender, 7(2), pp.95-113.

Fourchard, L. (2003). Urban Slums Reports: The Case of Ibadan, Nigeria.

Institute Francaisde Rechercheen Afrique. (IFRA), University of Ibadan.

[Online]. Available at:

https://www.ucl.ac.uk/dpuprojects/Global_Report/pdfs/Ibadan.pdf

(Accessed $2^{\text {nd }}$ August 2018).

Frost, G. \& Sullivan, D. (2012). Safer Cities: An Inevitable Trend in Urban

Development. Available at:

https://sg.nec.com/en_SG/pdf/brochures/PublicSafety/Safer_Cities White Paper.pdf (Accessed 10 ${ }^{\text {th }}$ September 2018).

Ghani, Z.A. (2017). A Comparative Study of Urban Crime Between Malaysia and Nigeria. Journal of Urban Management, 6(1), pp.19-29.

Grabosky, P.N. (1995). Burglary Prevention, Australian Institute of Criminology: Canberra.

Harries, K.D. (1974). The Geography of Crime and Justice, McGraw-Hill: New York.

Harris, B. (2001). As for Violent Crime That's Our Daily Bread: Vigilante Violence During South Africa's Period of Transition. Violence and Transition Series. Centre for the Study of Violence and Reconciliation: Johannesburg.

Hemed, M. (2015). Cross-sectional Studies. Geneva Foundation for Medical Education and Research (GFMER Tanzania) Training Course in Sexual and Reproductive Health Research Geneva 2015. [Online]. Available at: https://www.gfmer.ch/SRH-Course-2015/researchmethodology/pdf/Cross-sectional-studies-Hemed-2015.pdf

(Accessed $3^{\text {rd }}$ August 2018).

Hirtenlehner, H., \& Farrall, S. (2014). Is the 'Shadow of Sexual Assault' Responsible for Women's Higher Fear of Burglary? British Journal of Criminology, 54(6), pp.1167-1185.

Hopkins, A. (2007). Beyond Compliance Monitoring: New Strategies for Safety Regulators. Law and Policy,29(2), pp.210-225.

John, L. (2007). Vigilante Groups 'bad as gangs'. Available at: https://www.iol.co.za/news/south-africa/vigilante-groups-bad-asgangs-363902 (Accessed $2^{\text {nd }}$ August 2018).

John Howard Society of Ontario (JHSO). (1999). Population Trends and Crime: What Should we be Planning for? Available at: http://johnhoward.on.ca/wp-content/uploads/2014/09/facts-13population-trends-and-crime-what-should-we-be-planning-for-july1999.pdf (Accessed 23 ${ }^{\text {rd }}$ May 2018).

Kremer, K.P., Flower, A., Huang, J. \& Vaughn, M.G. (2016). Behaviour Problems and Children's Academic Achievement: A Test of GrowthCurve Models with Gender and Racial Differences. Children and Youth Services Review, 67, pp.95-104.

Kwaja, M. A. (2016). Informal Security Provision in Nigeria: Implications for Security Sector Governance, Centre for Security Governance. Available at: www.secgovcentre.com (Accessed 6 ${ }^{\text {th }}$ October 2018).

Landman, K. (2000). An Overview of Enclosed Neighbourhoods in South Africa, CSIR Publication: Pretoria, South Africa. 
Landman, K. \& Schönteich, M. (2002). Urban Fortresses: Gated Communities as a Reaction to Crime. The African Security Review, 11, pp.71-85.

Lasisi, M, Popoola, A. Adediji, A. Adedeji, O. \& Babalola, K. (2017). City Expansion and Agricultural Land Loss within the Peri-urban Area of Osun state, Nigeria. Ghana Journal of Geography, 9(3): pp.132-163.

Lee, M.R. (2006). The Religious Institutional Base and Violent Crime in Rural Areas. Journal for the Scientific Study of Religion, 45(3), pp.309-324.

Lippert, R. (2009). Signs of the Surveillant Assemblage: Privacy Regulation, Urban CCTV and Governmentality. Social and Legal Studies, 18(4), pp.505-522.

Liotta, P.H. \& Miskel, J.F. (2012). The Real Population Bomb: Megacities, Global Security \& the Map of The Future. Potomac Books, Inc: Washington D.C.

Loewen, L.J, Steel, G.D. \& Suedfeld, P. (1993). Perceived Safety from Crime in The Urban Environment. Journal of Environmental Psychology, 13(4), pp.323-331.

Marshall, B. \& Johnson, S. (2005). Crime in Rural Areas: A Review of the Literature for the Rural Evidence Research Centre, UCL London-Jill Dando Institute of Security and Crime Science: London.

Mathias, S.P. (2016). Police-Public Relations as a Potent Tool for Combating Crime, Insecurity, and Social Disorder in Nigeria. International Journal of Business and Management Invention, 5(11), pp.12-21.

McNamara, R. (1968). The Essence of Security: Reflections in Office, In Spiritual Dimension of Human and National Security, University of Ibadan Press: Ibadan, Nigeria, pp.13.

Meth, P. \& Buthelezi, S. (2017). New Housing/new Crime? Changes in Safety, Governance and Everyday Incivilities for Residents Relocated from Informal to Formal Housing at Hammond's Farm, Ethekwini. Geoforum, 82, pp.77-86.

Mohit, M.A., Ibrahim, M. \& Rashid, Y.R. (2010). Assessment of Residential Satisfaction in Newly Designed Public Low-Cost Housing in Kuala Lumpur, Malaysia. Habitat International, 34, pp.18-27.

Monk, H. (2014). Enforcing Good Behaviour is Fundamental to Education. Available at:

https://www.telegraph.co.uk/education/educationopinion/11132924/

Enforcing-good-behaviour-is-fundamental-to-education.html

(Accessed $3^{\text {rd }}$ August 2018).

Muggah, R. (2012). Researching the Urban Dilemma: Urbanisation, Poverty and Violence. Available at :

http://www.idrc.ca/EN/PublishingImages/Researchingthe-Urban-

Dilemma-Baseline-study.pdf (Accessed $4^{\text {th }}$ March 2018).

Mullin, C. \& Cherbonneau, M. (2011). Establishing Connections: Gender, Motor Vehicle Theft, and Disposal Networks. Justice Quarterly, 28(2), pp.278-302.

National Bureau of Statistics (NBS). (2016). Nigeria's National Bureau of Statistics, Crime Statistics: Reported Offences by Type and States. [Online]. Available at: www.nigerianstat.gov.ng (Accessed $3^{\text {rd }}$ August 2018).

National Centre for Victims of Crime. (2015). Engaging Communities and Empowering Victims. [Online]. Available at: 
http://victimsofcrime.org/docs/defaultsource/ncvrw2015/2015ncvrw stats urbanrural.pdf? sfvrsn=2 (Accessed $23^{\text {rd }}$ May 2018).

National Institute of Justice (NIJ). (2007). Investigative Uses of Technology:

Devices, Tools and Techniques. Available at:

https://www.ncjrs.gov/pdffiles1/nij/213030.pdf $\quad$ Accessed $9^{\text {th }}$ September 2018).

National Population Commission (NPC). (2010). 2006 Population and Housing Census: Priority Table Volume III. Abuja: National Population Commission of Nigeria. [Online]. Available at: http://www.population.gov.ng/ (Accessed 23 ${ }^{\text {rd }}$ May 2018).

Neuman, W.L. (1991). Social Research Methods: Quantitative and Qualitative Approaches.2nd edition. Allyn \& Bacon: London

Nganje, F. (2015). Moving Beyond Africa's Crisis of Institutions. Occasional Paper 222 Governance and APRM Programme. Johannesburg, South Africa: South African Institute of International Affair. Available at: https://www.saiia.org.za/occasional-papers/895-moving-beyondafrica-s-crisis-of-institutions/file (Accessed $2^{\text {nd }}$ August 2018).

Nolan, J. (2004). Establishing the Statistical Relationship between Population Size and UCR Crime Rate: Its Impact and Implications. Journal of Criminal Justice, 32, pp.547-555.

Nwankwo, U. \& Okolie-Osemene, J. (2016). A Study of Crime Reporting in Nigeria. [Online]. Available at:

http://www.nigeriawatch.org/media/html/Ukoji2016.pdf (Accessed $23^{\text {rd }}$ May 2018).

Ogboi, K.C. \& Eze, H. (2013). Enhancing Urban Security and Safety in Nigeria through Physical Planning and Management a paper presented at 44th Annual Conference of the Nigerian Institute of Town Planners in Owerri, Imo State, p.92.

Ogunleye-Adetona, C.I. (2013). Population Growth and Crime Rate Criminology Essay. Available at:

https://www.uniassignment.com/essaysamples/criminology/populati on-growth-and-crime-rate-criminology-essay.php?cref=1 (Accessed $20^{\text {th }}$ March 2018).

Oguntunde, P, Ojo, O. Omoleye, I. \& Oguntunde, A. (2018). Analysis of Selected Crime Data in Nigeria. Data in Brief, 19, pp.1242-1249.

Oladosu, R.O., Bwala, H.B. \& Muhammad, I. (2015). Application of Physical Planning and Design Strategies to Urban Violence and Crime Prevention in Nigeria. International Journal of Scientific \& Engineering Research, 6(3), pp.1633- 1642.

Omolola, O.O. \& Olaitan, O.O. (2013). An Appraisal of House Security Measures in Lagos, Nigeria. Architecture Research, 3(3), pp.21-25.

Oluseyi, O.F. (2006). Urban Land Use Change Analysis of a Traditional City from Remote Sensing Data: The Case of Ibadan Metropolitan Area, Nigeria. Humanity and Social Sciences Journal, 1(1), pp.42-64.

Osowole, O.I., Ugbechie, R., Aghamie, S.O., Nwoke, F., Balogun, K.O., Kazeem, F.O. \& Abolarin, M. (2014). Statistical Analysis of Poverty in Oyo-State: A Q2 -Approach 1. West African Journal of Industrial \& Academic Research, 12(1), pp.106-111.

Oteng-Ababio, M. (2016). Beyond Poverty and Criminalization: Splintering Youth Groups and Conflict of Governmentalities in Urban Ghana. Ghana Journal of Geography, 8(1), pp.51-78. 
Otu, N. (2004). The Development and Growth of the Nigeria Police Force from a Social Context Perspective. The Police Journal, 77(1), pp.1931.

Owusu, G., Wrigley-Asante, C., Oteng-Ababio, M. \& Owusu, A.Y. (2015). Crime Prevention through Environmental Design and BuiltEnvironmental Manifestations in Accra and Kumasi, Ghana. Crime Prevention and Community Safety, 17(4), pp.249-269.

Owusu, G. (2016). Introduction: Urban Crime and Poverty Nexus. Ghana Journal of Geography, 8(1), pp.1-10.

Pantazis, C. (2000). Fear of Crime, Vulnerability and Poverty. British Journal of Criminology, 40(3), pp.414-436.

Popoola, A., Tawose, O., Abatan, S., Adeleye, B., Jiyah, F. \& Majolagbe, N. (2015). Housing Conditions and Health of Residents in Ibadan North Local Government Area, Ibadan, Oyo State, Nigeria. Journal of Environmental Sciences and Resource Management, 7(2), pp.59-80.

Philip, J. C. (2008). Assessing Urban Crime and its Control: An Overview, NBER Working Paper no. 13781.

Randa, R. (2015). Residential Burglary: How the Urban Environment and Our Lifestyles Play a Contributing Role. Security Journal, 28(3), pp.326-328.

Rhew, I.C., Hawkins, J.D. \& Oesterle, S. (2011). Drug Use and Risk Among Youth in Different Rural Context. Health Place, 17(3), pp.775-783.

Ricciardelli, R. (2018). "Risk It Out, Risk It Out": Occupational and Organizational Stresses in Rural Policing. Police Quarterly, 14(3), pp.277-297.

Ross, C. E. (2000). Walking, Exercising and Smoking: Does Neighbourhood Matter? Social Science \& Medicine, 51(2), pp.265-274.

Salleh, A.G. (2008). Neighbourhood Factors in Private Low-Cost Housing in Malaysia. Habitat International, 32, pp.485-493.

Security and Defense Agenda. (2011). New Challenges in Urban Security. Available at: www.securitydefenceagenda.org (Accessed $26^{\text {th }}$ June 2018).

Sedgwick, P. (2014). Cross Sectional Studies: Advantages and Disadvantages. BMJ, 348, pp.1-2. Doi: 10.1136/bmj.g2276

Shichor, D., Decker, D. \& O'Brien, R. (1979). Population Density and Criminal Victimization: Some Unexpected Findings in Central Cities. Criminology, 17(2), pp.184-193.

Soul City Institute of Drug Abuse South Africa. (undated). A Review of Literature on Drug and Substance Abuse amongst Youth and Young Women in South Africa. Available at: https://www.soulcity.org.za/research/literature-reviews/soul-cityinstitute-drug-abuse-youth-south-africa.pdf. (Accessed $8^{\text {th }}$ September 2018).

Steffensmeier, D. \& Allan, E. (1996). Gender and Crime: Toward a Gendered Theory of Female Offending. Annual Review of Sociology, 22, pp.459-487.

Steffensmeier, D \& Allan, E. (2002). Gender and Crime - Differences between Male and Female Offending Patterns. Available at: http://www.encyclopedia.com/doc/1G2-3403000129.html (Accessed 23 ${ }^{\text {rd }}$ May 2018). 
Tade, O. \& Aderinto, A.A. (2012). Factors Influencing the Demand for Domestic Servants in Oyo State, Nigeria. International Journal of Child, Youth and Family Studies, 4(1), pp.521-545.

Timberlake, K. (2015). Safety Obsession Creates Risk of Fortress Cities. [Online]. Available at: www.ft.com (Accessed 10 $0^{\text {th }}$ December 2015).

Tomori, M.A. (2010). Ibadan Metropolitan Area and the Challenges to Sustainable Development, MACOS Consultancy Newsletter.

Townsley, M., Birks, D., Bernasco, W., Ruiter, S., Johnson, S.D., White, G. \& Baum, G. (2015). Burglar Target Selection: A Cross-national Comparison. Journal of Research in Crime and Delinquency, 52(1), pp.3-31.

Ukoji, V.N. \& Okolie-Osemene, J. (2016). A Study of Crime Reporting in Nigeria. Available at: http://www.nigeriawatch.org/media/html/Ukoji2016.pdf (Accessed $3^{\text {rd }}$ August 2018).

UNHabitat (2007a). Global Report on Human Settlements (2007). Enhancing Urban Safety and Security. Nairobi: UN-Habitat. Available at: http://www.unhabitat.org/pmss/listItemDetails.aspx?publicationID= 2432 (Accessed $4^{\text {th }}$ March 2018).

UNHabitat (2007b). Crime and Violence at a Glance, Global Report on Human Settlement 2007. Available at: www.unhabitat.org/downloads/docs/520399486Bk\%207.pdf (Accessed 15 ${ }^{\text {th }}$ November 2018).

United Nations Office for West Africa (UNOWA). (2007). Urbanisation and Insecurity in West Africa: Population movements, megacities and regional stability, UNOWA, Dakar.

Vanguard. (2011). Analysing Nigeria's Current Crime Surge. Available at: https://www.vanguardngr.com/2011/01/analysingnigeria $\%$ E2\%80\%99s-current-crime-surge/ (Accessed $3^{\text {rd }}$ August 2018).

Weisheit, R.A. \& Donnermeyer, J.F. (2000). Change and Continuity in Crime in Rural America. Criminal justice, 1(1), pp.309-357.

Wrigley-Asante, C. (2016). Gendered Perception of Crime and Safety: Insights from Different Socio-Economic Urban Neighbourhoods in Ghana. Ghana Journal of Geography, 8(1), pp.103-123.

Yusuf, S.A. (2003). Sampling Techniques. In Contemporary Social Science Research Methods: A Practical Guide, T. Agbola., L. Egunjobi. \& C.O. Olabutara (eds). MURLAB Search wisdom Educational Services Publishers: Lagos, Nigeria. pp.112-120. 